\title{
IDENTIFIKASI RESIDU PESTISIDA ORGANOFOSFAT PADA BAWANG MERAH DI KABUPATEN KULON PROGO
}

\section{IDENTIFICATION ON RESIDUAL ORGANOPHOSPHATE PESTICIDE IN ONION IN KULON PROGO}

\author{
Dian Prasasti*, Dyah Aryani Perwitasari \\ Fakultas Farmasi, Universitas Ahmad Dahlan Yogyakarta \\ Jl. Prof. Dr. Soepomo, SH, Janturan, Warungboto, Umbulharjo, Yogyakarta \\ "Penulis Korespondensi, e-mail : dianprasasti@gmail.com
}

\begin{abstract}
ABSTRAK
Di Indonesia pestisida organofosfat banyak digunakan pada tanaman buah dan sayuran seperti bawang merah. Pestisida organofosfat mengalami translokasi ke seluruh bagian tanaman sehingga residu pestisida organofosfat dapat tertinggal di umbi bawang merah yang dikonsumsi oleh masyarakat. Di Kabupaten Kulon Progo Provinsi DIY, pestisida organofosfat banyak digunakan terutama oleh petani bawang merah. Metode penelitian menggunakan rancangan observasional dan experimental. Sampel bawang merah diambil dari 10 petani yang tersebar di Kabupaten Kulonprogo. Kuisioner dibagikan kepada petani mengenai jenis pestisida yang digunakan dan waktu diaplikasikan oleh petani serta frekuensi penggunaan pestisida. Penentuan kadar organofosfat dilakukan dengan melakukan proses ekstraksi bawang merah dengan aseton, diklorometan, dan petroleum benzena kemudian dianalisis menggunakan kromatografi gas. Pestisida organofosfat yang diuji residunya adalah diazinon, parathion, ethion, profenofos, malation, dan klorpirifos. Hasil dari kuisioner kepada petani bawang merah, pestisida organofosfat yang digunakan adalah pestisida dengan bahan aktif profenofos dan klorpirifos dengan rata-rata penggunaan $0,5 \%(\mathrm{v} / \mathrm{v})$ sekali penyemprotan. Hasil analisis residu pestisida organofosfat menunjukkan bahwa sampel bawang merah dari 1 petani mengandung diazinon dengan kadar rata-rata 1,97 ppb. Residu pestisida pada bawang merah dari 9 petani menunjukkan hasil tidak terdeteksi untuk pestisida diazinon, parathion, ethion, profenofos, malation dan klorpirifos. Batas deteksi (LOD) untuk metode analisis pestisida organofosfat yang digunakan adalah diazinon 3,7 ppb, parathion 6,4 ppb, ethion 4,3 ppb, profenofos 4,8 ppb, malathion 1,24 ppb, dan klorpirifos $0,83 \mathrm{ppb}$.
\end{abstract}

Kata kunci : organofosfat, bawang merah, Kulon Progo

\section{ABSTRACT}

In Indonesia, many organophosphate pesticides used on fruit crops and vegetables such as onion, tomato, lettuce, and beans. Organophosphate pesticides has translocation to all parts of the plant, so organophosphate pesticide residues can be left in onion that consumed by the person. In Kulon Progo, Yogyakarta organophosphate pesticides are 
widely used especially by onion farmers. The research method used observational and experimental design. Samples were taken from 10 onion in Kulon Progo. The questionnaires were distributed to farmers on the types of pesticides used and the time applied by farmers as well as the frequency of the use of pesticides. Determination of organophosphates used extraction process with acetone, dichloromethane, and benzene peroleum as solvent then analyzed by GC. The results of a questionnaire to onion farmers, organophosphate pesticide used is the active ingredient diazinon, profenofos, and klorpirifos with an average usage of $1.5 \%(v / v)$. The results of the analysis of the active ingredient diazinon, profenofos, and klorpirifos showed the results of successive $3.7 \mathrm{ppb}, 4.8 \mathrm{ppb}$, and $0.83 \mathrm{ppb}$ with a detection limit respectively $3.7 \mathrm{ppb}, 4.8 \mathrm{ppb}$, and $0.83 \mathrm{ppb}$. GC analysis also showed only onions from one farmer containing pesticides diazinon levels of $1.97 \mathrm{ppb}$.

Keywords: organophospate, onion, Kulon Progo

\section{PENDAHULUAN}

Residu pestisida di lingkungan merupakan akibat dari penggunaan atau aplikasi pestisida tertentu yang ditujukan pada sasaran tertentu seperti pada tanaman dan tanah. Residu pestisida di lingkungan dapat juga sebagai akibat pestisida yang terbawa (drift) oleh gerakan air seperti sungai, air, tanah dan oleh gerakan angin/udara. Residu pestisida adalah zat kimia yang terkandung dalam hasil pertanian, bahan pangan atau pakan hewan baik sebagai akibat langsung maupun tak langsung dari penggunaan pestisida (Komisi Pestisida, 1997).

Organofosfat adalah senyawa kimia yang banyak digunakan dalam kebutuhan sehari-hari. Sebagai insektisida, fungisida, herbisida, dan bahan aditif pada industri (Eyer, 2003, Eddleston et al., 2004). Saat ini, ratusan bahan aktif dan ribuan formula tersedia di pasaran dunia US\$ 30 juta (Eddleston et al., 2002). Di seluruh dunia, kirakira 3.000.000 orang terpapar organofosfat tiap tahunnya, dengan 300.000 fatalitas diantaranya (Wu., 2001, Watson et al., 2003).

Pestisida organofosfat mengalami translokasi ke seluruh bagian tanaman. Translokasi terjadi melalui apoplast, symplast atau melalui mesofil dan pembuluh floem. Residu pestisida di tanaman dapat hilang seiring dengan proses pertumbuhan tanaman dan translokasi. Keberadaan pestisida pada tanaman pangan dipengaruhi oleh sifat fisiko-kimia pestisida tersebut. Pestisida dengan tekanan uap tinggi akan cepat hilang pada saat laju evaporasi ke udara tinggi. Pestisida dengan solubilitas dalam air 
yang rendah, sulit tercuci air hujan saat menempel pada lapisan lilin epidermis tanaman, sedangkan pestisida dengan solubilitas dalam air yang tinggi mudah terbawa air hujan dan mudah pula melakukan penetrasi ke dalam jaringan tanaman yang selanjutnya tertranslokasi ke seluruh bagian tanaman (Narwanti, 2013).

Menurut data WHO, paling tidak ditemukan 20.000 orang meninggal karena keracunan pestisida golongan organofosfat dan sekitar 5.000-10.000 mengalami dampak yang sangat berbahaya seperti kanker, cacat, mandul, dan hepatitis dalam setiap tahunnya (Priyanto, 2010).

Berdasarkan United Nations Press Release, 2004 di seluruh dunia diperkirakan 1 sampai 5 juta kasus keracunan terjadi tiap tahunnya dan beberapa ribu kasus diantaranya terjadi diantara petani. Sebagian besar kasus keracunan terjadi pada negara berkembang, karena kurangnya higienitas, informasi dan keterbatasan kontrol yang adekuat. Walaupun negara berkembang mengkonsumsi hanya 25\% dari kebutuhan dunia, data terkait kematian karena keracunan organofosfat mencapai jumlah 99\%. Beberapa penelitian menyatakan adanya kasus dan masalah serupa di Afrika (Ohayo-Mitoko et al., 2000; Dong, Simon, 2001), Asia (Weissmann-Brenner et al., 2002; Nagami et al., 2005; Van der Hoek, Konradsen, 2006; Sungurlekin et al., 2006), Europe (Kara et al., 2002; Nisse et al., 2002; Davanzo et al., 2004), and Americas (Fenske et al., 2000; Stallones and Beseler, 2002; Bonner et al., 2005; Pires et al., 2005).

Penggunaan pestisida sintetik yang tidak sesuai prosedur menyebabkan masalah kesehatan yang serius dalam tiga dekade terakhir pada negara berkembang. Bagaimanapun, lingkup masalah yang sebenarnya sulit dideteksi karena berbagai alasan. Petani dengan keracunan organofosfat yang ringan tidak melaporkan pada petugas kesehatan, karena akses jarak yang terlalu jauh dan mahal, atau karena petani takut kehilangan pekerjaannya. Petugas kesehatan di pedesaan sering gagal mendiagnosis keracunan, karena gejalanya terlalu umum, seperti pusing, mual, muntah (FAO, 2001).

Penggunaan pestisida golongan organofosfat di Indonesia masih sangat umum di kalangan pertanian untuk mengusir atau membasmi hama. Penggunaan pestisida golongan organofosfat ini jadi banyak dikhawatirkan penggunaannya karena selain mengusir hama pestisida ini dapat mengakibatkan keracunan pada petaninya langsung 
atau pada konsumen yang mengkonsumsi hasil pertanian yang disemprotkan pestisida golongan organofosfat ini. Keracunan akibat senyawa organofosfat akan menyebabkan otot-otot menjadi kejang dan penderita akan menggelepar. Gejala-gejala lainnya dari keracunan senyawa organofosfat adalah gemetar, penglihatan menjadi kabur, mual, lemah, kejang, diare dan sakit dada. Tanda-tanda lainya ialah berkeringat, mata berair, air liur banyak keluar, denyut jantung lebih cepat, dan muntah-muntah. Jika keracunan sangat serius, akan menyebabkan menggelepar, kehilangan reflek dan tidak sadarkan diri. Tanpa pertolongan segera dapat berakhir pada kematian (Tarumingkeng, 2004).

Di Indonesia pestisida organofosfat banyak digunakan pada tanaman buah dan sayuran seperti bawang merah, tomat, selada, dan kacang panjang. Badrudin (2013), menemukan kandungan pestisida organofosfat pada bawang merah di Kabupaten Brebes. Residu pestisida organofosfat dalam bawang merah yang ditemukan dalam penelitian tersebut adalah klorifiripos dengan kadar aman untuk dikonsumsi.

Upaya peningkatan produksi bawang merah sering menghadapi kendala berupa terjadinya serangan hama dan penyakit yang menyebabkan gagal panen atau minimal hasil panen berkurang. Salah satu cara yang terbukti dapat meningkatkan produksi bawang merah sebagai salah satu tindakan pemeliharaan tanaman adalah penggunaan pestisida. Sebagian besar petani beranggapan bahwa pestisida adalah sebagai "Dewa Penyelamat" yang sangat vital. Petani menyakini bahwa dengan aplikasi pestisida tanamannya akan terhindar dari kerugian akibat serangan jasad pengganggu tanaman yang terdiri dari kelompok hama, penyakit dan gulma. Keyakinan tersebut cenderung memicu penggunaan pestisida dari waktu ke waktu meningkat dengan pesat. Pestisida telah merupakan bagian yang tidak terpisahkan dari sistem pertanian di Indonesia. Penggunaan pestisida tertinggi adalah pada lahan hortikultura dan diikuti pada lahan tanaman pangan (Ardiwinata, 2008 dalam Badrudin dan Jazilah, 2013). Frekuensi aplikasi pestisida dapat mencapai 3-5 kali dalam seminggu dengan menggunakan lebih dari dua jenis pestisida, bahkan dapat mencapai tujuh jenis pestisida yang digunakan sekaligus secara dioplos. Pestisida adalah bahan kimia beracun, pemakaian pestisida yang berlebihan dapat menjadi sumber pencemar bagi bahan pangan, air, dan lingkungan hidup (Atmawidjaja et al., 2004). Salah satu dampak dari penggunaan 
pestisida adalah tertinggalnya residu pestisida di dalam produk pertanian dan di dalam tanah, serta bahaya residu bagi kesehatan manusia (Sastroutomo, 1992).

Penentuan kadar organofosfat dapat dilakukan dengan metode GC-MS. Berdasarkan SNI no. 7313 tahun 2008 tentang batas maksimum residu pada golongan organofosfat dengan bahan aktif klorpirifos adalah sebesar $1 \mathrm{mg} / \mathrm{kg}$ (Tarumingkeng, 2004).

\section{METODE PENELITIAN}

\section{Pengambilan sampel}

Sampel bawang merah diambil dari 10 petani di kecamatan Sentolo, Kabupaten Kulonprogo pada bulan Februari 2016. Petani yang bawang merahnya disampling, dibagikan kuisioner mengenai jenis pestisida yang digunakan dan waktu aplikasi pestisida oleh petani, serta frekuensi penggunaan pestisida. Bawang merah disampling pada waktu dilakukan panen, yaitu 45-50 hari setelah waktu tanam.

\section{Jalannya Penelitian}

Sampel bawang merah yang diambil secara acak dari petani sebanyak 500 gram kemudian dianalisis residu organofosfat di Laboratorium Penelitian dan Pengujian Terpadu Universitas Gadjah Mada dengan Gas Cromatography (GC). Analisis residu dilakukan dengan sampel bawang merah dicincang, dicampurkan jadi satu dan diambil sebanyak 10 gram. Sampel kemudian ditambahkan $\mathrm{Na}_{2} \mathrm{SO}_{4}$ anhidrat kemudian dihomogenkan selama 2-3 menit. Sampel kemudian diekstraksi dengan larutan campuran diklorometana : aseton : petroleum benzena (1:1:1) sebanyak $10 \mathrm{~mL}$. Campuran didiamkan sampai residu terpisah. Lapisan atas diambil kemudian $1 \mu \mathrm{L}$ diinjeksikan ke dalam instrumen GC. Replikasi dilakukan 3 kali. Pestisida organofosfat yang diuji residunya adalah diazinon, parathion, ethion, profenofos, malation dan klorpirifos.

\section{HASIL DAN PEMBAHASAN}

Petani bawang merah di Kabupaten Kulon Progo, menggunakan pestisida organofosfat dalam membasmi insektisida pada tanaman. Selain pestisida jenis organofosfat, petani juga menggunakan pestisida golongan karbamat dan organoklorin. Pada penelitian ini diambil bawang merah dari 10 petani yang tersebar di Kabupaten 
Kulon Progo. Sepuluh petani yang hasil panennya berupa bawang merah adalah petani dengan inisial A, B, C, D, E, F, G, H, I dan J.

Petani bawang merah diberikan kuisioner mengenai waktu tanam, jenis pestisida yang digunakan, waktu penggunaan pestisida, frekuensi penggunaan pestisida, serta banyaknya penggunaan pestisida sekali semprot. Hasil pengisian kuisioner yang diberikan kepada petani, jenis pestisida organofosfat yang digunakan adalah jenis klorpirifos dan profenofos dimana rata-rata pemakaian pestisida tersebut adalah $0,5 \%$ $(\mathrm{v} / \mathrm{v})$. Petani pestisida melakukan penyemprotan setiap pagi selama waktu tanam (45-50 hari), dimana jenis pestisida yang disemprotkan berbeda-beda setiap hari dan seringkali dilakukan pencampuran pestisida sekali semprot.

Bawang merah yang dianalisis residunya adalah bawang merah yang diambil pada waktu dilakukan panen, yaitu 45-50 hari setelah waktu tanam. Sampel bawang merah yang dianalisis diambil secara random. Bawang merah dari 10 petani $\mathrm{A}, \mathrm{B}, \mathrm{C}, \mathrm{D}, \mathrm{E}, \mathrm{F}$, $\mathrm{G}, \mathrm{H}, \mathrm{I}$ dan $\mathrm{J}$ dilakukan analisis kandungan residu pestisida jenis organofosfat dengan instrumen Gas Chromatography (GC).

Instrumen GC yang digunakan menggunakan detektor Flame Photometric Detector (FPD) dengan kolom HP-5. Kondisi instrumen pada penelitian ini adalah Kecepatan alir gas $22 \mathrm{~mL} / \mathrm{menit}$, suhu injeksi $230{ }^{\circ} \mathrm{C}$, program suhu $29{ }^{\circ} \mathrm{C}$, suhu detektor $250{ }^{\circ} \mathrm{C}$. Jenis pestisida organofosfat yang dianalisis adalah diazinon, parathion, ethion, profenofos, malathion, dan klorpirifos. Dari hasil pengukuran standar diperoleh data waktu retensi dan luas area disajikan pada Tabel I.

Tabel I. Waktu retensi dan luas area larutan standar pestisida organofosfat

\begin{tabular}{lll}
\hline Pestisida & $\begin{array}{l}\text { Waktu Retensi } \\
\text { (menit) }\end{array}$ & Luas Area \\
\hline Diazinon & 4,359 & 195,7569 \\
Parathion & 6,796 & 6,0834 \\
Ethion & 14,240 & 17,3204 \\
Profenofos & 10,818 & 5,4905 \\
Malation & 22,762 & 14,9587 \\
Klorpirifos & 2,397 & 10,8812 \\
\hline
\end{tabular}

Penentuan kadar residu pestisida dihitung melalui persamaan

$$
\text { Kadar }=\frac{\frac{\text { Luas area sampel }}{\text { Luas area standar }} \times \text { Kadar standar } \times \text { volume akhir }}{\text { Berat sampel }} .
$$

Hasil pengukuran kadar pestisida disajikan pada Tabel II. 
Tabel II. Pengukuran kadar pestisida organofosfat pada bawang merah

\begin{tabular}{lll}
\hline Sampel & Residu Pestisida & $\begin{array}{c}\text { Kadar Rata-rata } \\
(\mathbf{p p b})\end{array}$ \\
\hline $\mathrm{A}$ & Diazinon & 1,975 \\
& Parathion & Tidak terdeteksi \\
& Ethion & Tidak terdeteksi \\
& Profenofos & Tidak terdeteksi \\
& Malation & Tidak terdeteksi \\
& Klorpirifos & Tidak terdeteksi \\
\hline B,C,D,E, F, G, H, I, J & Diazinon & Tidak terdeteksi \\
& Parathion & Tidak terdeteksi \\
& Ethion & Tidak terdeteksi \\
& Profenofos & Tidak terdeteksi \\
& Malation & Tidak terdeteksi \\
& Klorpyrifos & Tidak terdeteksi \\
\hline
\end{tabular}

LOD pestisida : diazinon 3,70 ppb; Parathion 6,40 ppb; Ethion 4,30 ppb; Profenofos 4,80 ppb; Malation 1,24 ppb ; klorpirifos $0,83 \mathrm{ppb}$

Pengukuran pestisida diazinon yang terdekteksi dengan metode GC yang digunakan terlihat pada tabel 2. Pestisida diazinon yeng terdeteksi merupakan 1 sampel dari 10 sampel yang dianalisis. Pestisida diazinon terdeteksi pada waktu retensi berkisar 4,4 menit sehingga rata-rata kadar pestisida diazinon adalah 1,975 ppb dengan standar deviasi (SD) 1,974 dan standar deviasi relatif (SDR) 1,001\%. SDR digunakan untuk mengetahui ketepat ulangan metoda yang digunakan. Dari hasil yang diperoleh terlihat bahwa ketepat ulangan dari metoda GC masih dalam batas yang diperbolehkan yaitu dengan harga standar deviasi relatif yang didapatkan dibawah 20\%. Ketepatan ulangan ini sangat dipengaruhi oleh jumlah volume dalam setiap penginjeksian, karena pengerjaan injeksi ini dilakukan pada volume yang kecil sekali yaitu $1 \mathrm{uL}$. Kelebihan atau kekurangan sedikit saja pada waktu pengambilan sample volume injeksi akan memberikan luas puncak yang berbeda (Lestari, 2011).

Tabel III. Hasil pengukuran pestisida diazinon pada sampel bawang merah petani A dengan metode GC

\begin{tabular}{cclc}
\hline Sampel & $\begin{array}{c}\text { Waktu Retensi } \\
\text { (menit) }\end{array}$ & $\begin{array}{c}\text { Luas } \\
\text { Area }\end{array}$ & Kadar (ppb) \\
\hline 1 & 4,444 & 81,689 & 2,062 \\
2 & 4,447 & 75,297 & 1,885 \\
3 & 4,450 & 78,052 & 1,979 \\
\hline
\end{tabular}

Pestisida organofosfat yang digunakan oleh petani A, B, C, D, E, F, G, H, I, dan J adalah jenis profenofos dan klorpirifos, tetapi untuk seluruh petani kedua pestisida tersebut tidak terdekteksi. Hal ini dapat dimungkinkan karena beberapa hal, diantaranya telah terdegradisinya pestisida tersebut dan pestisida telah menguap sebelum dilakukan proses analisis. Sementara bawang merah dari 1 petani terdeteksi mengandung pestisida jenis diazinon, sementara dari hasil kuisioner yang diberikan kepada petani, petani tidak menggunakan pestisida jenis diazinon. Hal ini dapat dimungkinkan pestisida diazinon 
diaplikasikan tercampur dalam pestisida yang digunakan ataupun petani menggunakan jenis pestisida diazionon tetapi tidak mengakui menggunkannya. Batas Minimum Residu (BMR) yang diizinkan 0,5 ppm sehingga pestisida diazionon yang terdeteksi masih dalam batas aman.

Studi yang dilakukan EPA (Environmental Protection Agency) tahun 1999 profenofos memiliki waktu degradasi 7-8 hari, sedangkan diazinon yang diaplikasikan akan hilang dalam dua minggu. Degradasi etion yaitu 10 hari di alam, karena faktor hidrolisis dan mikroorganisme. Malation terdegradasi dalam waktu tiga hari, sedangkan paration pada kondisi akan langsung terhidrolisis dalam hitungan jam (Ekadewi, 2007). Menurut Gilani, 2010 pestida jenis klorpirifos terdegradasi dalam waktu 1 tahun.

Selain perbedaan persistensi masing-masing organofosfat, sifat fisika - kimia organofosfat juga diduga mempengaruhi konsentrasi beberapa organofosfat yang tidak terdeteksi oleh alat kromatografi gas. Berdasarkan analisis yang dilakukan, kondisi operasional kromatografi gas menggunakan suhu kolom $220{ }^{\circ} \mathrm{C}$, sedangkan beberapa organofosfat hanya memiliki titik didih tidak lebih dari $220{ }^{\circ} \mathrm{C}$ (Ekadewi, 2007). Hal tersebut menyebabkan beberapa organofosfat sudah hilang menguap atau rusak lebih dulu sebelum mencapai detektor alat kromatografi gas.

\section{KESIMPULAN}

Dari hasil penelitian dan pembahasana, dapat disimpulkan bahwa sembilan sampel bawang merah dari 10 sampel bawang merah tidak mengandung pestisida diazinon, parathion, ethion, profenofos, malation, dan klorpirifos. Satu sampel bawang merah dari 10 sampel bawang merah yang diambil mengandung pestsida jenis diazinon dengan kadar 1,97 ppb dan tidak mengandung pestisida diazinon, parathion, ethion, profenofos, malation, dan klorpirifos. Pesitisida diazinon dari satu sampel bawang merah yang terdeteksi masih dalam batas aman.

\section{DAFTAR PUSTAKA}

Atmawidjaja, S., D.H. Tjahjono, Rudiyanto, 2004, Pengaruh Perlakuan terhadap Kadar Residu Pestisida Metidation pada Tomat. Acta Pharmaceutica Indonesia. Vol. 29 No. $2: 1-9$.

Badrudin, U., Jazilah, S., 2013, Analisis Residu Pestisida Pada Tanaman Bawang Merah (Allium ascalonicum L.) di Kabupaten Brebes, Pena Jurnal Ilmu Pengetahuan dan Teknologi, Vol. 24 No.1, : 75-86.

Davanzo F, Settimi L, Faraoni L, Maiozzi P, Travaglia A, Marcello I. 2004. Agricultural pesticide-related poisonings in Italy: cases reported to the Poison Control Centre of Milan in 2000-2001. Epidemiol Prev. Vol. 28, No.6:330-7. 
Dong X, Simon MA, 2001, The epidemiology of organophosphate poisoning in urban Zimbabwe from 1995 to 2000. Int J Occup Environ Health. Vol. 7, No.4:333-8.

Eddleston, M, Phillips, MR, 2004, Self poisoning with pesticides. BMJ .Vol. 328:42.

Ekadewi, P., 2007, Bioindikator Pencemaran Insektisida Organofosfat pada Tanah Pertanian. Skripsi, Program Studi Teknik Lingkungan, Fakultas Teknik Sipil dan Lingkungan, Institut Teknologi Bandung, Bandung.

Eyer, P. 2003, The role of oximes in the management of organophosphorus pesticide poisoning. Toxicol Rev. Vol. 22:165.

FAO, 2001, http://www.fao.org/agriculture/crops/obsolete-pesticides/what-dealing/obspes/en/, diakses tanggal 26 Nov. 15

Fenske RA, Lu C, Curl CL, Shirai JH, Kissel JC., 2005, Biologic monitoring to characterize organophosphorus pesticide exposure among children and workers: an analysis of recent studies in Washington State. Environ Health Perspect. Vol.113, No.11:1651-7.

Gilani, S.T., 2010, Klorpirifos Degradation in Soil and Its Effect on Soil Microorganisms. The Journal of Animal \& Plant Sciences, Vol. 20, No 2:99-102.

Kara IH, Güloğlu C, Karabulut A, Orak M., 2002, Sociodemographic, clinical, and laboratory features of cases of organic phosphorus intoxication who attended the Emergency Department in the Southeast Anatolian Region of Turkey. Environ Res. Vol. 88, No.2:82-8.

Komisi Pestisida, 1997, Metode Pengujian Residu Pestisida dalam Hasil Pertanian, Departemen Pertanian, 377.

Lestari, 2011, Metode Kromatografi Gas Untuk Analisis Pestisida Organopospat, Sainmatika, Vol. 3 No. 1. 
Nagami H, Nishigaki Y, Matsushima S, Matsushita T, Asanuma S, Yajima N, Usuda M, Hirosawa M., 2005, Hospital-based survey of pesticide poisoning in Japan 1998-2002. Int J Occup Environ Health. Vol. 11, No.2:180-4.

Narwanti, I., Sugiharto, E., Anwar, C., 2013, Residu Pestisida Aldrin Dan Dieldrin Pada Sampel Tanah Dan Air Di Desa Srigading Kecamatan Sanden Kabupaten Bantul, Pharmaciana, Vol. 3, No. 2 : 23-28.

Nisse P, Deveaux M, Tellart AS, Dherbecourt V, Peucelle D, Mathieu-Nolf M., 2002, Aldicarb poisoning: review of cases in the North of France between 1998 and 2001. Acta Clin Belg Suppl. Vol. 1;12-5.

Ohayo-Mitoko GT, Kromhout H, Simwa JM, Headerik D., 1999, Self reported symptoms and inhibition of acetylcholines-terase activity among Kenyan agricultural workers. Occup Environ Med; 57:195-200.

Pires DX, Caldas ED, Recena MC. 2005.Pesticide poisoning in Dourados, Mato Grosso do Sul State, Brazil, 1992/2002. Cad Saude Publica. Vol. 21, No. 3:804-14.

Priyanto. 2010. ToksikologiMekanisme, Terapi Antidotum, dan Penilaian Risiko. Leskonfi (Lembaga Studi dan Konsultasi Farmakologi). Jabar.

Sastroutomo, S.S, 1992, Pestisida : Dasar-dasar dan Dampak Penggunaannya, PT Gramedia Pustaka Utama, Jakarta.

Stallones L, Beseler C. 2002. Pesticide poisoning and depressive symptoms among farm residents. Ann Epidemiol. Vol. 12, No. 6:389-94.

Tarumingkeng, R. C. 2004. Inseksida: Sifat, Mekanisme Kerja dan Dampak Penggunaannya. Universitas Kristen Krida Wacana, Jakarta. 
Van der Hoek W, Konradsen F. 2006. Analysis of 8000 hospital admissions for acute poisoning in a rural area of Sri Lanka. Clin Toxicol (Phila). Vol. 44, No. 3:22531.

Watson, WA, Litovitz, TL, Rodgers, GC, et al. 2002 Annual Report of the American Association of Poison Control Centers Toxic Exposure Surveillance System. Am J Emerg Med . Vol. 21:353.

Weissmann-Brenner A, Friedman LM, David A, Vidan A, Hourvitz A. 2002. Organophosphate poisoning: a multihospital survey. Isr Med Assoc J. Vol. 4, No. 7:573-576.

Wu, ML, Deng, JF, Tsai, WJ, 2001. Food poisoning due to methamidophoscontaminated vegetables. $J$ Toxicol Clin Toxicol Vol. 39:333. 